\title{
Attitudes of Egyptian Teachers towards Computers
}

\author{
Samira M. Bakr \\ Ministry of Education, Egypt
}

\begin{abstract}
Appraisal of teacher attitudes towards computers has gained importance following the widespread availability of microcomputers in schools all around the world. This study aims at investigating Egyptian teachers' attitudes towards computers in terms of gender and years of teaching experience. Attitudes of a sample of 118 public school teachers, 53 (45\%) male and 65 (55\%) female, were assessed using 'The Attitude Towards Computer Instrument' (ATCI), developed by Shaft et al (2004), which is a Likert type instrument with three factors of affective, cognitive, and behavioral. The gathered data were analyzed using an analysis of variance (ANOVA). Findings showed that the Egyptian public school teachers' attitudes towards computers are positive. There were no significant differences in terms of gender and teaching experience. Recommendations for further research are provided.
\end{abstract}

Keywords: Attitudes towards computers; ATCl; Teachers' attitudes; Egyptian teachers; Microcomputers in schools

\section{Introduction}

Throughout the world there is awareness of the fundamental role of new information and communication technologies (ICTs) in the field of education. Theoretical and empirical studies have considered the importance of ICTs in the process of teaching and learning. Recently, the Ministry of Education in Egypt has also put great efforts and major financial investments to implement ICT into teaching and learning environments. The philosophy of the Ministry of Education (MOE) in Egypt regarding the use of technology in schools comes from the common believe that technology can make education and learning scientific, understandable, efficient, effective, and interesting. A special unit within the MOE, called the Technology Development Center (TDC), has been formed to coordinate the MOE's effort to infuse technology into schools (Warschauer, 2004).

In 1994, the TDC within the MOE planned for many ambitious projects to introduce computers into schools to modernize the education system. A great project was launched to equip every school with the latest desktop technology. Most of primary schools, all preparatory and secondary schools were provided with multimedia rooms and computer labs. Multimedia rooms have 2 to 3 computers, with LCD panels, large screens, and collections of curriculumbased courseware, and teachers were asked to bring in their classes on a regular basis. Computer labs were equipped with ten to twenty computers. These computers are used for teaching courses in computing (operating systems, computer applications, and programming languages). 
Evaluation studies and reports showed that the multimedia rooms and computer labs are rarely used by teachers, and administrators do not encourage or support teachers and students to use them to enhance their teaching and learning (Warschauer, 2003a). Although MOE has invested a lot in equipping schools with computers, this investment has not been complemented by the development of appropriate human and social resources. Much greater emphasis should be placed on the development and evaluation of human and social resources through implementation of long-term teacher training programs and community involvement (Warschauer 2003b). Despite the expansion of ICT in Egyptian schools, the body of empirical research investigating the use of computers in classrooms and its relationship with other variables is still relatively small.

Actually, the user's acceptance is considered an important element in the successful implementation of technology in the instructional/educational setting, and which is greatly influenced by the users' attitudes towards technology. Moreover, Myers \& Halpin (2002), Yildirim (2000), and Teo (2008) believe that attitudes towards computers and trust in using them in education are two major predictors for teachers' future use of technology in classrooms. Levin and Wadmany (2006-2007) emphasize the importance of a clear focus on teachers' attitudes, values, and beliefs as a primary focus in supporting teacher learning. A negative attitude may lead to computer resistance (Sheiderman, 1980), a phenomenon that can be found among experienced as well as inexperienced users (Negron, 1995). A negative attitude may even lead to defamation or sabotage of computer technology (Gibson \& Rose, 1986). Gaining an appreciation of the teachers' attitudes towards computers use may provide useful insights into technology integration, and acceptance as well as usage of technology in teaching and learning.

Aiken (1996) conceptualizes an attitude as a "learned predisposition to respond positively to certain objects, situations, institutions, concepts or persons." As implied in this definition, attitudes possess cognitive (beliefs, knowledge, and expectations), affective (motivational and emotional), and performance (behavior or actions) components. A person's attitude toward a computer is influenced by a variety of aspects, e.g., computer liking, computer confidence, computer anxiety or comfort (Delcourt \& Kinzie, 1993), achievement (Bandalos \& Benson, 1990), usefulness, and value (Pelton \& Pelton, 1996), age and gender (Colley \& Comber, 2003; Kutluca, 2010), subject area and years of computer use (Teo, 2008), levels of technology use in classrooms (Al-Zaidiyeen et al., 2010) and self-efficacy (Rovai \& Childress, 2002).

Chen and Chang (2006) indicate that attitudes, skills, and practice are interrelated variables. Their results also suggest that aspects of teacher technology competence vary according to number of teaching years, home computer access, and length of in-service training. In most cases, many of these factors interact with one another to impact on attitudes towards computers. However, the effect of gender on the formation of a person's computer attitudes is still a matter of debate and research findings are inconsistent. Previously, several studies have addressed this factor and revealed that males have a more positive attitude towards computers compared to females (Krendl 1989; Loyd1987).

On the contrary, Barrier and Margavio's study (1992) showed that males attitude towards computer was more negative than that of females. Surprisingly, Yildirim's study (2010) which investigated 120 pre-service teachers' attitude towards computer showed no gender differences in attitude towards computer. Kay (1990) has stated that gender-related studies have produced conflicting results. Thus, understanding gender-based attitudinal difference is likely to have an important implication. 
The relationship between years of teaching experience and computer attitude has not been given much consideration. In the Egyptian context, the only study (Sadik, 2006) which proved that more experienced teachers showed more positive attitudes towards computers. Accordingly, the researcher believes that there is a need for more studies to explore the relationship between years of teaching experience and attitudes towards computers.

More specifically, there are several studies conducted in Egypt and other countries in the region investigating the attitudes of teachers towards computers in schools. These studies may provide useful findings for better understanding the situation in Egypt.

Abdulkafi (2006) explored the attitude of high school English as Foreign Language (EFL) teachers in Syria toward ICT and investigated the relationship between computer attitude and five independent variables: computer attributes, cultural perceptions, computer competence, computer access, and personal characteristics (including computer training background). The findings suggest that teachers have positive attitude towards ICT in education and their attitudes were predicted by computer attributes, cultural perceptions, and computer competence. Moreover, the results clearly emphasized the importance of teachers' vision of technology itself, their experience in using it, and the cultural conditions surrounding its introduction into schools, on shaping teachers' general attitude towards technology and its subsequent diffusion in their educational practice.

Saracaloglu et al. (2010) analyzed the attitude of 419 candidate teachers towards computer in terms of various variables. Data were collected through two data gathering instruments. The study revealed that attitude of students towards computer was "very positive".

Al-Zaidiyeen et al. (2010) investigated the level of ICT use for educational purposes by teachers in Jordanian rural secondary schools; the study demonstrated the importance of teachers' attitude towards the use of ICT for educational purposes. A questionnaire was used for data collection and it was distributed among 650 teachers in Jordan. The survey included questions concerning the level of ICT use as well as questions related to the attitude of teachers towards the use of ICT. The findings revealed that teachers' level of ICT use for educational purpose was low although their attitude towards the ICT use was positive.

Cavas et al. (2010) study explored Turkish primary science teachers' attitudes towards ICT in education and (then) the relationship between teachers' attitudes and the factors related to teachers' personal characteristics (gender, age, computer ownership at home, and computer experience). The instrument (STATICTE) was developed by researchers and administered to 1071 science teachers. The results indicated that the Turkish science teachers have positive attitudes toward ICT; no gender differences have been traced in their attitudes towards ICT but differences were found in terms of their age, their computer skills (experience) and their ownership of computers at home.

The present study aims to find out computer attitudes of Egyptian teachers based on gender and teaching experience at different public schools in Egypt. In accordance with this objective, the study specifically focuses on the following research questions: (1) According to the attitude towards Computer Instrument (ATCl) and its subscales, what is the overall profile of Egyptian teachers' attitude towards computers; (2) Is there a difference on computer attitude in terms of gender; and (3) Is there a difference on computer attitudes according to years of teaching experience of teachers? 


\section{Methods}

\section{Research Model}

Survey methodology was used in this study. This methodology helps researchers to obtain general results about the sample (Karasar, 2005). One of the main reasons employing survey methodology was that it could enable the researcher to go to the field and to collect data on the topic in question from a small sample of the population in a short period. As Robson (1997) stated surveys are often cross-sectional studies. That is, the focus is on the make-up of the sample and the state of affairs in the population at just one point in time. Researchers also suggest that it is convenient to carry out a survey study when the researcher has time and resource problems (Cohen et al. 2000). The survey in this study included a section assessing the independent variables; gender, teaching experience and dependent variables; attitude towards computer.

\section{Sample}

The participants in this study are 118 teachers at governmental secondary schools in Egypt. According to gender variable, $53(45 \%)$ male and 65 (55\%) female teachers participated in this study. Concerning the teaching experience variable, 27 teachers have less than 10 years (22\%), 21 have more than 10 years (18\%), 29 have more than 15 years (25\%), and 41 have more than 20 years (35\%). Table 1 illustrates the demographic of the sample as Table 2 shows the years of teaching experience.

Table1. Demographics of the Sample

\begin{tabular}{|l|r|r|}
\hline Sex & Number & Percentage \\
\hline Male & 53 & 44.9 \\
\hline Female & 65 & 55.1 \\
\hline Total & 118 & 100.0 \\
\hline
\end{tabular}

Table 2: Years of Teaching Experience

\begin{tabular}{|l|r|r|}
\hline Teaching Experience & Frequency & Percentage \\
\hline $1-10$ years & 27 & 22.0 \\
\hline $11-15$ years & 21 & 17.8 \\
\hline $16-20$ years & 29 & 24.6 \\
\hline $20+$ years & 41 & 34.7 \\
\hline Total & 118 & 100.0 \\
\hline
\end{tabular}

\section{Data Gathering}

Data were collected from all participants during the first semester of the academic year 2010. Before distributing all questionnaires, the researcher introduced the topic of the research to 
the participants who volunteered to respond to the questionnaire after being assured that data collected from them will not be used for teacher evaluation.

The tool used for collecting data required for this study is a questionnaire that consists of two parts. The first part provides information about the participants' demographic background: gender, teaching experience and the subject they teach. The second part is 'The Attitude towards Computer Instrument (ATCI), developed by Shaft et al. (2004). The ATCl is relatively short so as not to be tiresome for the participants. ATCl was developed using the semantic differential which is especially suited to assessing basic attitudes (Mehling, 1959) and has yielded consistently high reliability and validity scores across applications (Miller, 1964).

The items were randomly distributed throughout the ATCI, and four items were reverse scaled to limit response bias. Reverse scaling was accomplished by switching the anchors within an item so that a positive response became a low score (rather than a high score). Reverse scaling decreases the likelihood that a participant will select a response (usually high or low) and give that answer for every item. When using the instrument, the researcher recodes the score associated with reverse scaled items such that all positive responses are counted as a high score. The semantic differential format allows the reverse scaling to be removed by switching the anchors on those items per the preferences of the researcher.

ATCl is an eight-item scale that consists of three components of computer attitudes. The first component is the 'Affective' aspect which is composed of two items ( 2 and 7) and measures feelings towards computer, the 'Cognitive' aspect which is composed of two items ( 1 and 4) that measures the individual's beliefs about the usefulness of computers, and the 'Behavioral' aspect which is subdivided into two components, ease of use ( 3 and 6 ) and productivity ( 5 and 8). The total score of the eight items gives the general attitude towards computers.

\section{Data Analysis}

Responses of public school teachers to the questionnaire were statistically analyzed according to gender and teaching experience variables via SPSS software. The means (X) and standard division (SS) scores were computed for each attribution. In the study, some parametric techniques such as t-test; one-way analysis of variance (ANOVA) based on the significance level of $\alpha=0.5$ were used to test the significance of the differences. In order to determine sources of the differences on means found in ANOVA, Scheffe test was used as a multiple comparison test.

\section{Findings}

Attitude towards computer was measured in terms of the Affective, Cognitive, and Behavioral subscales in the ATCl (Shaft et al. 2004). All 118 participants responded to all items in ATCl and no missing data were found in the questionnaire.

Table 3 presents the participants' mean scores with the standard deviations of the three subscales. The participants scored the lowest on the Affective aspect (mean $=8.47$ ) followed by the cognitive aspect (mean $=10.37$ ). The mean scores for the behavioral aspect is (mean $=$ 15.46). 
The means suggest that participants were more positive about their behavior towards computers than their perceptions of the affection of the computer and their cognition of the computer. At the global level, the overall computer attitude is well above the mid-point of the scale $(28.00)$ and this finding indicated that participants generally held a positive attitude towards the computer.

Table 3. Mean Scores and Standard Deviations

\begin{tabular}{|l|r|r|r|}
\hline & $\mathbf{n}$ & $\times$ & SS \\
\hline ATCl & 118 & 31.73 & 5.51 \\
\hline Affective & 118 & 8.47 & 2.51 \\
\hline Cognitive & 118 & 10.37 & 2.97 \\
\hline Behavioral & 118 & 15.46 & 3.31 \\
\hline
\end{tabular}

In order to determine any gender differences in the attitude scores among teachers in public schools, an independent-samples t-test was conducted. The independent-sample t-test scores can be seen in Table 4.

Table 4. Gender Differences in Computer Attitudes

\begin{tabular}{|c|c|c|c|c|c|c|}
\hline Subscale & Gender & $n$ & Mean & SD & df & $t$ \\
\hline \multirow[t]{2}{*}{ Affective } & Male & 53 & 5.17 & 3.161 & \multirow[t]{2}{*}{116} & \multirow[t]{2}{*}{2.294} \\
\hline & Female & 65 & 6.49 & 3.078 & & \\
\hline \multirow[t]{2}{*}{ Cognitive } & Male & 53 & 10.55 & 3.154 & \multirow[t]{2}{*}{116} & \multirow[t]{2}{*}{0.658} \\
\hline & Female & 65 & 10.18 & 2.828 & & \\
\hline \multirow[t]{2}{*}{ Behavioral } & Male & 53 & 15.60 & 2.970 & \multirow[t]{2}{*}{116} & \multirow[t]{2}{*}{0.406} \\
\hline & Female & 65 & 15.35 & 3.594 & & \\
\hline \multirow[t]{2}{*}{ ATCl } & & 53 & 31.32 & 5.079 & \multirow[t]{2}{*}{116} & \multirow[t]{2}{*}{0.694} \\
\hline & Female & 65 & 32.03 & 5.871 & & \\
\hline
\end{tabular}

The independent-sample $t$-test scores show no significant gender differences $(t=-0,690$; $p>0,05)$ among the teachers' attitude towards computer. Based on scores, female teachers have a relatively higher $(x=32.03)$ attitude towards computers than males $(x=31.32)$. Also in terms of sub-scales, female teachers have a more positive attitude in the affective aspect $(X=$ 6.49) than male teachers $(x=5.17)$.

To investigate the relationship between teachers' attitude towards computer and years of teaching experience, scores for years of teaching experience were categorized into four levels: from 1 to 10 , from 11 to 15 , from $16-19$, and from 20+ years of teaching experience. The ANOVA tests were used to analyze the differences among the four groups and their computer attitude.

The findings showed that teachers' attitude towards computer on the cognition aspect were affected by their teaching experience. Through a series of Scheffé tests (post hoc tests), it can 
be concluded that in terms of teaching experience, there is no significant difference between the teachers' attitude towards computer (Table $5 \& \&$ ).

Table 5. Descriptive Statistics on Teaching Experience

\begin{tabular}{|c|c|c|c|c|c|c|c|c|}
\hline & \multicolumn{2}{|c|}{$\begin{array}{c}\text { From } 1 \text { to } 10 \\
\text { Years } \\
(n=27)\end{array}$} & \multicolumn{2}{|c|}{$\begin{array}{c}\text { From } 11 \text { to } 15 \\
\text { Years } \\
(n=50)\end{array}$} & \multicolumn{2}{|c|}{$\begin{array}{c}\text { From } 16 \text { to } 19 \\
\text { Years } \\
(n=78)\end{array}$} & \multicolumn{2}{|c|}{$\begin{array}{c}\text { From } 20+\text { Years } \\
\quad(n=41)\end{array}$} \\
\hline & $\times$ & SS & $\times$ & SS & $\times$ & SS & $x$ & SS \\
\hline ATCl & 32.25 & 6.32 & 31.51 & 4.77 & 30.62 & 5.42 & 32.42 & 5.62 \\
\hline Affective & 18.14 & 2.39 & 8.45 & 2.73 & 9.07 & 2.58 & 8.27 & 2.37 \\
\hline Cognitive & 9.29 & 3.11 & 10.58 & 2.92 & 9.59 & 2.92 & 11.69 & 2.4 \\
\hline Behavioral & 15.92 & 3,31 & 15.25 & 2.62 & 14.66 & 3.24 & 15.93 & 3.91 \\
\hline
\end{tabular}

Table 6. Summary of One-way ANOVA on Class Level

\begin{tabular}{|l|r|r|r|r|r|}
\hline & Source & Sum of Squares & df & Mean Square & \multirow{2}{*}{ F } \\
\hline \multirow{3}{*}{ Affective } & Between Groups & 67.659 & 3 & 22.553 & \multirow{2}{*}{2.318 not sig } \\
\cline { 2 - 5 } & Within Groups & 1109.121 & 114 & 9.729 & \\
\cline { 2 - 5 } & Total & 1176.780 & 117 & & \\
\hline \multirow{3}{*}{ Cognitive } & Between Groups & 107.382 & 3 & 35.794 & \multirow{2}{*}{4.410 sig } \\
\cline { 2 - 5 } & Within Groups & 925.373 & 114 & 8.117 & \\
\cline { 2 - 5 } & Total & 1032.754 & 117 & & \multirow{2}{*}{.813 not } \\
\hline \multirow{3}{*}{ ATCl } & Between Groups & 26.959 & 3 & 7.986 & \\
\cline { 2 - 5 } & Within Groups & 1260.405 & 114 & 11.056 & \multirow{2}{*}{.449 not } \\
\cline { 2 - 5 } & Total & 1287.364 & 117 & & \\
\cline { 2 - 5 } & Between Groups & 41.614 & 3 & 13.871 & \\
\cline { 2 - 5 } & Within Groups & 3520.590 & 114 & 30.882 & \\
\cline { 2 - 5 } & Total & 3562.203 & 117 & & \\
\hline
\end{tabular}

\section{Conclusions and Recommendations}

The findings of this study indicate that teachers' attitude towards computer at governmental schools is relatively high and that no significant gender differences exist among them. This suggests that both Egyptian male and female teachers at governmental schools have the same perception about computer.

Concerning gender differences in teachers' attitude towards computer, Shapkaa \& Ferrarib, (2003) reports displayed some differences while others like Gressard and Loyd (1986), Woodrow (1992) did not display any significant gender differences. However, results of other studies showed that female teachers manifested higher levels of anxiety in their attitude towards computers more than male teachers (Sadik, 2005; Samak, 2006).

According to North and Noyes (2002), using ICTs is widely perceived as a masculine activity and their research provided evidence for a correlation between gender and technophobia (cited in 
Samak, 2006). Female teachers have been found to be more anxious and less confident computer users in most of the studies than male teachers. Research on gender and computing has often reported, though not conclusively, that male teachers have more experience and make more use of computers (Balka \& Smith, 2000; Brosnan \& Lee, 1998). Research on computer self-efficacy in general also revealed that males on average tend to acquire computer self-efficacy faster than females (Todman, 2000).

Gender differences in teachers' attitude towards computer are almost absent in the present study and this conforms to previous research that revealed the change of female computer users' attitude. For example, females today appear to be more comfortable when using computers than before and this may have resulted in lessening the barriers perceived by females in the lack of training opportunities for them (Ray \& Harris, 1999). Moreover, North and Noyes (2002) believed that the increased use of computers in teaching and learning at schools - similar to the situation at Egyptian schools - has diminished gender differences among teachers' attitude towards computer.

In terms of teaching experience, results prove that there are no significant differences among teachers' attitude towards using computer at governmental schools. This result does not support Sadik's study (2006) which indicates that teachers who have longer teaching experience are more likely to appreciate the importance of computer use in schools. However, this can be attributed to the attitude of the Egyptian Ministry of Education, which has encouraged the use of computers in teaching at schools as an effective method to provide a high quality of education for students. This can be exemplified in providing in-service computer programs to most of the teachers of all levels at the governmental schools in Egypt regardless to their teaching experience.

More studies are needed to investigate teachers' attitudes towards computers in terms of years of teaching experience, subject matters, teachers' monthly income, self-efficacy and inservice training programs attended. In addition, some research may tackle the relationship between teachers' attitudes and students' attitudes towards computer in Egyptian schools at different levels. Ministry of Education in Egypt is requested to provide more in-service training for teachers, on using technology in the classroom and to support them with more effective instructional materials and teaching models. In addition, courses related to instructional media and technologies at the Faculties of Education should be re-constructed and made obligatory if possible.

\section{References}

Albirini, A. (2006). Teachers' attitudes toward information and communication technologies: The case of Syrian EFL teachers. Computers \& Education, 47(4), 373-398.

Aiken, L. R. (1996). Rating scales and checklists: Evaluating behavior, personality, and attitudes. Canada: John Wiley \& Sons.

Al-Zaidiyeen, N., Mei, L., \& Fook, F. (2010). Teachers' attitudes and levels of technology use in classrooms: The case of Jordan schools. International Education Studies, 3(2), 211-218.

Barrier, T. \& Margavio, T. (1992). Pretest-posttest measure of introductory computer students' attitude towards computers. Journal of Information System Education, 5(3), 53-58 
Barry, C. \& Gibbons, L. (1990). Information systems technology: Barriers and challenges to implementation. Journal of Nursing Administration, 20(2), 40-42.

Broos, A. (2005). Gender and information and communication technologies (ICT) anxiety: Male self-assurance and female hesitation. Cyber Psychology \& Behavior, 8, 21-31.

Bandalos, D. \& Benson, J. (1990). Testing the factor structure invariance of a computer attitude scale over two grouping conditions. Educational and Psychological Measurement, 50(1), 49-60.

Brosnan, M. \& Lee, W. (1998) Across-cultural comparison of sex differences in computer attitudes and anxieties: The United Kingdom and Hong Kong. Computers in Human Behavior, 14(4), 559-577.

Cavas, B., Cavas, P., Karaoglan, B. \& Kisla, T. (2010). A study on science teachers' attitude toward information and communication technologies in education. The Turkish Online Journal of Educational Technology, 8(2), 20-32.

Chen, J. \& Chang, C. (2006). Using computers in early childhood classrooms: Teachers' attitudes, skills and practices. Journal of Early Childhood Research, 4(2), 169-188.

Cohen, L., Manion, L., \& Morrison, K. (2000). Research method in education (Fifth Edition). New York: Routledge.

Colley, A. \& Comber, C. ( 2003) Age and gender differences in computer use and attitudes among secondary school students: What has changed? Educational Research, 45(2), 155-165.

Egyptian Association for Education Technology Conference (2000, May). Recommendation. Cairo.

Francis-Pelton, L. \& Pelton, T. W. (1996). Building attitudes: How a technology course affects preservice teachers'attitudes about technology. Retrieved from http://www.math. byu.edu/ Ifrancis/tim's-page/attitusite.htm

Gibson, S. \& Rose, M. (1986). Managing computer resistance. Personal Computing, 4(5), 201204.

Gressard, C. P. \& Loyd, B. H. (1986). Validation studies of a new computer attitude scale. Association for Educational Data Systems Journal, 18(4), 295-301.

Karasar, N. (2005). Bilimsel arastirma yontemleri (15. baski). Ankara: Nobel.

Kay, R. (1990) Predicting student teacher commitment to the use of computers. Journal of Educational Computer Research, 6, 299-309.

Krendl, K., Broihier, M., \& Fleetwood, C. ( 1989). Children \& computer: Do sex-related differences persist? Journal of Communication, 39, 89-93.

Kutluca, T. (2010) Investigation of teachers' computer usage profiles and attitudes toward computers. International Online Journal of Science, 2(1), 81-97.

Levin, T. \& Wadmany, R. (2007). Teachers' beliefs and practices in technology-based classrooms: A developmental view. Journal of Research on Technology in Education, 39(2), 157-181.

Lightbody, M. \& Jones, L.S. (1998, April). A comparison of the efficacy of different models of technology instruction for inservice teachers. Paper presented at the Annual meeting of the National Association for Research in Education. San Diego, CA. 
Loyd, B., Loyd, D., \& Gressard , C. (1987) Gender and computer experience as factors in computer attitudes of middle school students. Journal of Early Adolescence, 7, 13-19.

Marasovic, C., Kenney, C., Elliott, D., \& Sindhusake, D. (1997). Attitudes of Australian nurses toward implementation of a clinical information system. Computers in Nursing, 15(2), 91-98.

Mehling, R. (1959). A simple test for measuring the intensity of attitudes. Public Opinion Quarterly, 23(4), 576-578.

Ministry of Education. (1999). Mubarak and education: The national project for developing education. Cairo: Ministry of Education Press.

Myers, J. M. \& Halpin, R. (2002). Teachers' attitudes and use of multimedia technology in the classroom: Constructivist-based professional development training for school districts. Journal of Computing in Teacher Education, 18(4), 133-140.

Negron, J. A. (1995). The impact of computer anxiety and computer resistance on the use of computer technology by nurses. Journal of Nursing Staff Development, 11(3), 172-175.

North, A. S. \& Noyes, J. M. (2002). Gender influences on children's computer attitudes and related differences. Journal of Communication, 39, 89-93.

Ray, C. M., Sormunen, C., \& Harris, T. M. (1999). Men's and women's attitudes toward computer technology: A comparison. Office Systems Research Journal, 17(1), 1-8.

Robson, C. (1997). Real world research: A resource for social scientists and practitionerresearchers. Oxford: Blackwell.

Rovai, A. \& Childress, M. (2002). Explaining and predicting resistance to computer anxiety reduction among teacher education students. Journal of Research on Technology in Education, 35(2), 226-235.

Sadik, A. (2005). Factors influencing teachers' attitudes towards personal use and schools use of computers: New evidence from a developing nation. Evaluation Review, 2(1), 1-29.

Sadik, A. (2006). Factors influencing teachers' attitudes toward personal use and school use of science teaching. (ERIC Document Reproduction Service No. ED 418 869).

Samak, Z. A. (2006). An exploration of Jordanian English language teachers' attitudes, skills, and access as indicator of information and communication technology integration in Jordan (Unpublished doctoral thesis). Tallahassee: Florida State University.

Shaft, T., Sharfman, M. \&Wu, W. (2004). Reliability assessment of the attitude towards computers instrument (ATCI). Computers in Human Behavior, 20, 661-689.

Shapkaa, J. and Ferrarib, M. (2003) Computer-related attitudes and actions teacher candidates. Computers in Human Behavior, 20(3), 319-334.

Sheiderman, B . (1980) Software psychology. Cambridge, MA: Winthrop.

Teo, T . (2008 a) Pre-service teachers' attitudes towards computer use: a Singapore survey. Australasian Journal of Educational Technology, 24, 413-424.

Teo, T. (2008). Assessing the computer attitudes of students: an Asian perspective. Computers in Human Behavior, 24(4), 1634-1642. 
Warschauer, M. (2003a). The allures and illusions of modernity: Technology and educational reform in Egypt. Educational Policy Analysis Archive, 11(38). Retrieved from http://epaa.asu.edu/ojs/article/view/266.

Warschauer, M.(2003b). Dissecting the "digital divide": A case study in Egypt. Information Society, 19(4), 297-304.

Warschauer, M. (2004). The rhetoric and reality of aid: Promoting educational technology in Egypt. Globalisation, Societies and Education, 2(3), 377-90.

Woodrow, J. (1992). The influence of programming training on the computer literacy and attitudes of pre-service teachers. Journal of Research on Computing in Education, 25(2), 200-218.

Woodrow, J. (1991). A comparison of four computer attitude scales. Journal of Educational Computing Research, 7, 165-187.

Yaghmaie, F., Jayasuriya, R., \& Rawstorne, P. (1998).Computer experience and computer attitude: A model to predict the use of computerized information systems. Human Computer Interaction, 52(2), 895-899.

Yildirim, S. \& Kaban, A. (2010). Attitudes of pre-service teachers about computer supported education. International Journal of Human Sciences, 7(2). Retrieved 1 July 2011 from http://www.insanbilimleri.com/ojs/index.php/uib/article/view/1102/576

Yildirim, S. (2000). Effects of an educational computing course on preservice and inservice teachers: A discussion and analysis of attitudes and use. Journal of Research on Computing in Education. 34(4), 479-95.

Correspondence: Samira Mohamed Bakr, Ph.D., Curricula Specialist and Teacher Trainer, Center for Curricula and Instructional Material Development (CCIMD), Ministry of Education, Cairo, Egypt. 